\title{
Production, antioxidant characterization and application of active starch-based films containing essential oils for beef packaging
}

\author{
Produção, caracterização antioxidante e aplicação de fillmes ativos à base de amidlo contendo óleos \\ essenciais para embalagens de carne bovina \\ Producción, caracterización antioxidante y aplicación de películas activas a base de almidón que \\ contienen aceites esenciales para el envasado de carne de vacuno
}

Received: 06/07/2021 | Reviewed: 06/15/2021 | Accept: 06/21/2021 | Published: 07/04/2021

Lucinéia Aparecida Cestari

ORCID: https://orcid.org/0000-0002-5649-3700

State University of Maringa, Brazil

E-mail: lucicestari@gmail.com

Monica Regina da Silva Scapim

ORCID: https://orcid.org/0000-0001-7818-6624

State University of Maringa, Brazil

E-mail: mrsscapim@uem.br

Grasiele Scaramal Madrona

ORCID: https://orcid.org/0000-0002-8837-8424

State University of Maringa, Brazil

E-mail: gsmadrona@uem.br

Fábio Yamashita

ORCID: https://orcid.org/0000-0002-9280-0683

State University of Londrina, Brazil

E-mail: fabioy@uel.br

Polyana Batoqui França Biondo

ORCID: https://orcid.org/0000-0003-3689-6112

State University of Maringa, Brazil

E-mail: polyanabf@msn.com

Venício Macêdo Carvalho

ORCID: https://orcid.org/0000-0002-2875-7799

State University of Maringa, Brazil

E-mail: venicio_@hotmail.com

Edinéia Bonin

ORCID: https://orcid.org/0000-0002-0242-1170

State University of Maringa, Brazil

E-mail: bonin_in@hotmail.com

Ivanor Nunes do Prado

ORCID: https://orcid.org/0000-0003-1058-7020

State University of Maringa, Brazil

E-mail: inprado@uem.br

\begin{abstract}
The objective of this work was to study the antioxidant activity of biodegradable and active packaging containing essential oils. Seven types of active packaging were produced. In beef, lipid oxidation was measured using the thiobarbituric acid reactive substance test (TBARS); a microbiological analysis in beef was performed for Salmonella spp., coagulate positive Staphylococcus spp., Clostridium sulphite reducer and E. coli; the measurements were carried out on days $0,3,6,9,12$ and 15 in triplicate. All packaging had exhibited antioxidant capacities and acted as an antioxidant in meat. The packages containing clove exhibited the highest total phenolic and antioxidant capacity $(P<$ 0.05 ), and when used in beef were most effective against lipid oxidation. The use of oregano, clove and rosemary incorporated in active biodegradable starch based reduced microbial development and acted effectively against rancidity by maintaining the quality of meat stored under refrigerated conditions for 15 days.
\end{abstract}

Keywords: Antioxidant capacity; Essential oils; Lipid oxidation; Preservation.

\section{Resumo}

O objetivo deste trabalho foi estudar a atividade antioxidante de embalagens biodegradáveis e ativas contendo óleos essenciais. Foram produzidos sete tipos de embalagens ativas. Na carne bovina, a oxidação lipídica foi medida pelo teste do ácido tiobarbitúrico (TBARS); foi realizada análise microbiológica na carne bovina para Salmonella spp., 
Staphylococcus spp. coagulase positivo, Clostridium sulfito redutor e E. coli. As medidas foram realizadas nos dias 0 , 3, 6, 9, 12 e 15, em triplicata. Todas as embalagens exibiram capacidade antioxidante e atuaram como antioxidante na carne. As embalagens contendo cravo-da-índia apresentaram maior capacidade fenólica total e antioxidante $(\mathrm{P}<0,05)$ e, quando utilizadas na carne bovina, foram mais eficazes contra a oxidação lipídica. O uso de orégano, cravo e alecrim incorporados em embalagem biodegradável ativa à base de amido reduziu o desenvolvimento microbiano e atuou de forma eficaz contra a rancificação, mantendo a qualidade da carne armazenada em refrigeração por 15 dias.

Palavras-chave: Capacidade antioxidante; Óleos essenciais; Oxidação lipídica; Preservação.

\section{Resumen}

El objetivo de este trabajo fue estudiar la actividad antioxidante de envases activos y biodegradables que contienen aceites esenciales. Se produjeron siete tipos de envases activos. En la carne de vacuno, la oxidación de lípidos se midió mediante la prueba de sustancia reactiva con ácido tiobarbitúrico (TBARS); se realizó un análisis microbiológico en bovinos para Salmonella spp., Staphylococcus spp. coagulado positivo, Clostridium sulfito reductor y E. coli. Las mediciones se realizaron los días $0,3,6,9,12$ y 15 por triplicado. Todos los envases habían mostrado capacidades antioxidantes y actuaban como antioxidantes en la carne. Los envases que contenían clavo de olor exhibieron la capacidad fenólica y antioxidante total más alta $(\mathrm{P}<0.05)$, y cuando se usaron en carne de res fueron más efectivos contra la oxidación de lípidos. El uso de orégano, clavo y romero incorporados a base de almidón biodegradable activo redujo el desarrollo microbiano y actuó eficazmente contra la rancidez al mantener la calidad de la carne almacenada en condiciones refrigeradas durante 15 días.

Palabras clave: Capacidad antioxidante; Aceites esenciales; Oxidación de lípidos; Preservación.

\section{Introduction}

Microbial growth and lipid oxidation are the main causes of deterioration in meat quality (Radha et al., 2014). In order to minimise this effect, the use of oils and extracts from plants has been studied in animal diets (Monteschio et al., 2017; Rivaroli et al., 2016) or for direct application in meat and meat products, as these treatments can generate changes, mainly in the odor and flavor sensory characteristics (Kempinski et al., 2017; Vital et al., 2016). In this context, new alternatives such as the application of antimicrobial and antioxidant products in packaging have been tested (Appendini \& Hotchkiss, 2002; Bolumar et al., 2011; Conde et al., 2011). Active and intelligent packaging introduces new perspectives for food packaging, such as the concept of intentional substance migration; for instance, the migration of preservatives and antioxidants from the package into the food (Gómez-Estaca et al., 2014; Realini \& Marcos, 2014).

Allied to this, there is the growing demand by consumers for natural antioxidant and antimicrobial products due the potential toxicological effects of synthetic antioxidants. Essential oils (EOs) are rich in phenolic compounds. Recent studies have revealed that oregano, clove, rosemary, and other essential oils are active against many microorganisms and delay lipid oxidative degradation (Anthony et al., 2012; Burt, 2004; Javier Camo et al., 2011; Kempinski et al., 2017; Shah et al., 2014). Many essential oils exhibit antioxidant and antimicrobial activities due to their high content of phenolic compounds. Anthony et al. (2012) ranked 423 essential oils; the most effective antioxidants were present in eight of the tested botanical families, including oregano (thymol and carvacrol), clove (eugenol) and rosemary ( $\alpha$-pinene). These compounds act to delay the onset or to slow down the rate of oxidation, and are linked to damage to the membrane of bacterial cells, resulting in an increase in disintegration and permeability (Appendini \& Hotchkiss, 2002; Burt, 2004).

Thus, the objective of this work was to study the antioxidant activity in biodegradable and active packaging containing essential oils, and the application of packaging in beef, stored under refrigerated conditions for 15 days.

\section{Material and Methods}

\subsection{Raw materials}

Oregano oil (Origanum vulgare, 221 lot, CAS number: 84012-24-8), clove leaf oil (Eugenia caryophyllus, 213 lot, CAS number: 8015-97-2) and rosemary oil (Rosmarinus officinalis, 153 lot, CAS number: 8008-45-5) were provided by the company Ferquima Ind. and Com. Ltda from São Paulo, Brazil. This work is a quantitative research (Pereira et al., 2018). Was chosen to 
use these oils according to preliminary results of our research group Biondo et al. (2017), in which was evaluated these three oils from the same lot, and 15 others, in relation to antioxidant capacity through DPPH, ABTS, FRAP and ORAC assays and also identification of bioactive compounds by gas chromatography-mass spectrometry (GC-MS).

Longissimus lumborum (LL) (from the $10^{\text {th }}$ to $12^{\text {th }}$ ribs) was obtained from eight young bulls $(1 / 2$ Simmental vs. $1 / 2$ Nellore) finished in a feedlot for 168 days and fed with a high concentrate diet according to Eiras et al. (2016). Animal slaughter was performed in a slaughterhouse near of experimental farm. Animals had an average weight of $480 \mathrm{~kg}$, carcass dressing of $54 \%$ and $\mathrm{pH}$ of 5.74, measured 24 hours after slaughter Eiras et al. (2016).

\subsection{Film production and experimental design}

The extrusion process was applied to develop the packaging material and was divided in two stages: the extrusion process and reprocessing the pellets were extruded again for film formation. The films were produced at the Laboratory of Food Science and Technology Department at the State University of Londrina. Starch (Indemil, Brazil) and glycerol (Synth P.A, Brazil) were used to obtain a thermoplastic starch (TPS); added poly (butylene adipate-co-terephthalate) (PBAT; BASF, Germany) by Ecoflex ${ }^{\circledR}$ S BX 7025. Oregano, clove and rosemary oils were homogenised during the first stage. Were films extruded directly from the mixture of TPS (13\% glycerol and 45\% starch), Ecoflex (40\%) and 2\% essential oils, these mixtures were then extruded in order to obtain pellets by using twin screw extruder (model D-20 series 9002.001, BGM, São Paulo, Brazil). In the second stage, the extruder was fed manually with the pellets (blends) and the film formed through the blowing technique (film balloons) by injecting compressed air inside and outside the balloon, both polyurethane rollers speed and coil were held constant as described by Cestari et al. (2015).

Seven different types of packaging were prepared according to the experimental design mix by partially replacing starch by oregano, clove, rosemary oils and their mixtures (Table 1). After obtaining the films, they were manually cut and heat-sealing machine to make pouches $(15 \mathrm{~cm}$ x $20 \mathrm{~cm})$.

Table 1. Composition (\%) of biodegradable active packaging.

\begin{tabular}{lccc}
\hline \multirow{2}{*}{ Treatment } & & Essential oils, $\%$ & Rosemary \\
\cline { 2 - 4 } & Oregano & Clove & 0 \\
OR2 & 2 & 0 & 0 \\
CL2 & 0 & 2 & 2 \\
RO2 & 0 & 0 & 0 \\
ORCL1 & 1 & 1 & 1 \\
ORRO1 & 1 & 0 & 1 \\
CLRO1 & 0 & 1 & 0.66 \\
ORCLRO1/3 & 0.66 & 0.66 & \\
\hline
\end{tabular}

OR2: $2 \%$ oregano oil. CL2: $2 \%$ clove oil. RO2: $2 \%$ rosemary oil. ORCL1: $1 \%$ oregano oil and 1\% clove oil. ORRO1: $1 \%$ oregano oil and 1\% rosemary oil. CLRO1: $1 \%$ clove oil and 1\% rosemary oil. ORCLRO1/3: 0.66\% oregano, clove and rosemary oils. Source: Authors.

The Longissimus lumborum samples was cut into six steaks at a thickness of $3.5 \mathrm{~cm}(300 \mathrm{~g}$ each) with a knife and placed in active packaging randomly, sealed and stored chilled at $4^{\circ} \mathrm{C}$.

\subsection{Determination of thickness films}

Film thickness was determined using a manual micrometer (Mitutoyo, Japan). The final thickness was determined by the arithmetic mean of 10 measurements random conditioned for $48 \mathrm{~h}$ at $64 \% \mathrm{RH}$. 


\subsection{Water vapor permeability (WVP)}

To determine the WVP of the films, the gravimetric method adapted from the standard E 96-95 of ASTM was used. The gradient relative humidity was used $2 \%-53 \%$. The vapor permeation ratio (WVPR) was obtained with Equation 1 .

$$
W V P R=\left(\frac{m}{t}\right) \cdot\left(\frac{1}{A}\right)
$$

Where $\mathrm{m} / \mathrm{t}$ is the angular coefficient of the mass gain line $(\mathrm{g})$ versus time (day), and $\mathrm{A}\left(\mathrm{m}^{2}\right)$ is the sample permeation area. The WVP $\left(\mathrm{g} \mathrm{Pa} \mathrm{day}^{-1} \mathrm{~m}^{-1}\right)$ was calculated (Equation 2$)$.

$$
W V P=\left[\frac{W V P R \cdot s t}{s p \cdot\left(R H_{1}-R H_{2}\right)}\right]
$$

Where st is the mean sample thickness $(\mathrm{m}), \mathrm{sp}$ is the water vapor saturation pressure at the assay temperature $(\mathrm{Pa}), \mathrm{RH}_{1}$ is the relative humidity of the desiccator and $\mathrm{RH}_{2}$ is the relative humidity in the interior of the permeation cell. The tests were conducted in duplicate.

\subsection{Determination of total phenolic and antioxidant activity of the active packaging}

\subsubsection{Active packaging extract preparation}

The packaging was cut manually with scissors in small pieces, then immersed in solution $50 \%$ ethanol $/ \mathrm{H}_{2} \mathrm{O}(\mathrm{v} / \mathrm{v})$ in a proportion of 1:10 (w/v) under magnetic stirring for $1 \mathrm{~h}$ in the dark room according to (Michiels et al., 2012), with modifications. After filtration, the ethanolic extracts were used for antioxidant analysis.

\subsubsection{Total soluble phenolic compound content}

The content of soluble phenols of samples were determined in triplicate according to the Folin-Ciocalteu method (Singleton \& Rossi, 1965), with modifications described by (Wu et al., 2005). The $0.25 \mathrm{~mL}\left(2.50 \mathrm{mg} \cdot \mathrm{mL}^{-1}\right.$ ) aliquot of ethanolic extract solution (see 2.4.1) was mixed with $0.25 \mathrm{~mL}$ of Folin-Ciocalteau reagent (diluted in distilled water 1:1, v/v), $0.50 \mathrm{~mL}$ of saturated sodium carbonate solution and $4.0 \mathrm{~mL}$ of distilled water. The mixture was kept in the dark for 25 min and then centrifuged at $2000 \mathrm{rpm}$ for $10 \mathrm{~min}$. Absorbance at $725 \mathrm{~nm}$ was measured using a spectrophotometer (GENESYS $10 \mathrm{uv}$, Thermo Scientific, Madison, USA). A methanolic solution of gallic acid with a concentration of $0-250 \mathrm{mg} \cdot \mathrm{L}^{-1}$ was used for the calibration: $\mathrm{y}=0.0273+5.9170 \times 10^{-3} x, \mathrm{R}^{2}=0.998$. The results are expressed as $\mu$ mol expressed as gallic acid equivalents per gram of sample $\left(\mu \mathrm{mol} \mathrm{GA} \mathrm{g}{ }^{-1}\right)$.

\subsubsection{1,1-diphenyl-2-picrylhydrazyl (DPPH) assay}

The DPPH radical scavenging capacity was measured in triplicate according to (Brand-Williams et al., 1995), with modifications described by (Ma et al., 2011). The ethanolic extract solutions $(25 \mu \mathrm{L})$ were mixed with $2 \mathrm{~mL}$ of a $6.25 \times 10^{-5} \mathrm{~mol}$ $\mathrm{L}^{-1}$ DPPH radical methanolic solution. The absorbance of the resulting solutions was measured at $517 \mathrm{~nm}$ in a UV-visible spectrophotometer (GENESYS 10uv Scanning, Thermo Scientific, USA) after the solutions stood protected from light at room temperature for $30 \mathrm{~min}$. Methanolic solutions of Trolox (6-hydroxy-2,5,7,8-tetramethylchromane-2-carboxylic acid) in the range of $0-2000 \mu \mathrm{mol} \mathrm{L}^{-1}$ were used for calibration: $\mathrm{y}+0.686-2.90 \times 10^{-4} x, \mathrm{R}=0.997$. The results are expressed as $\mu \mathrm{mol}$ Trolox

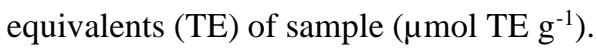

\subsubsection{Oxygen radical absorbance capacity (ORAC)}

The ORAC methodology was performed as described by (Zulueta et al., 2009) at $37^{\circ} \mathrm{C}$ using a Perkin Elmer fluorescent microplate reader (VICTOR ${ }^{\text {TM }}$ X4 Multilabel Plate Reader, USA) using a 96-well black microplate in which excitation/emission 
was measured from the top of the plate. Sample extracts were diluted with $0.075 \mathrm{~mol} \mathrm{~L}^{-1}$ phosphate buffer ( $\mathrm{pH} 7.0$ ) solution to an appropriate concentration to be within the range of the standard curve $\mathrm{y}=0.8547+0.3635 x, \mathrm{R}^{2}=0.9845$. This $0.075 \mathrm{~mol} \mathrm{~L}^{-1}$ phosphate buffer ( $\mathrm{pH} 7.0$ ) solution was used as a blank and to dissolve the Trolox standards for the ORAC assay. A $25 \mu \mathrm{L}$ portion of the diluted samples was added to each well of the microplate followed by $150 \mu \mathrm{L}$ of $0.004 \mu \mathrm{mol} \mathrm{L}^{-1}$ fluorescein sodium salt solution and was then inserted into the fluorescent microplate reader for $5 \mathrm{~min}$ to stabilise the temperature. Then, $25 \mu \mathrm{L}$ of $2,2^{\prime}$ azobis (2 - amidino-propane) dihydrochloride (AAPH) solution, diluted in $0.075 \mathrm{~mol} \mathrm{~L}^{-1}$ phosphate buffer (pH 7.0) with a concentration of $161.1 \mathrm{mmol} \mathrm{L}^{-1}$, was added to each well. Readings were initiated immediately at $1 \mathrm{~min}$ intervals for $30 \mathrm{~min}$. The wavelengths of excitation and emission were 485 and $515 \mathrm{~nm}$, respectively.

The final ORAC values were calculated using linear regression: $y=a x+b$ between the Trolox concentration $\left(\mu \mathrm{mol} \mathrm{L} \mathrm{L}^{-1}\right)$ and the net area under the fluorescein decay curve according to (Ou et al., 2001). The results are expressed as $\mu$ mol Trolox equivalents (TE) $\mathrm{g}^{-1}$ of essential oil ( $\mu \mathrm{mol} \mathrm{TE} \mathrm{g}^{-1}$ ).

\subsection{Lipid oxidation}

The malondialdehyde (MDA) content was quantified using the TBA-reactive substances (TBARS) assay (Pfalzgraf et al., 1995). The sample (5 g) was mixed with TCA solution (7.5\% TCA, $0.1 \%$ EDTA and $0.1 \%$ gallic acid) (10 mL), homogenised using a vortex, then centrifuged at $4000 \mathrm{rpm}$, at $4{ }^{\circ} \mathrm{C}$, for $15 \mathrm{~min}$. The supernatant was filtered and mixed (1:1 v/v) with TBARS reagent $(1 \% \mathrm{TBA}, 562.5 \mathrm{mM} \mathrm{HCl}, 15 \% \mathrm{TCA})$. The mixture was boiled $\left(100^{\circ} \mathrm{C}\right)$ for $15 \mathrm{~min}$, cooled, and then the absorbance was measured at $532 \mathrm{~nm}$. The concentrations were determined using an MDA standard curve (using 1,3,3-tetramethoxypropane), ranging from 0 to $60 \mathrm{mM}$. Results are expressed as $\mathrm{mg} \mathrm{MDA} \mathrm{kg}{ }^{-1}$ of sample.

\subsection{Microbiological analysis}

On days $0,3,6,9,12$ and 15 , triplicate packages from each treatment were aseptically opened and crushed; a $25 \mathrm{~g}$ portion was homogenised with $225 \mathrm{~mL}$ of peptone water (Merck) for $1 \mathrm{~min}$ to carry out the initial dilution $\left(10^{-1}\right)$, then proper serial dilutions (until $10^{-5}$ ) were performed.

Violet Red Bile Agar (VBR, Merck) was used for total coliforms and Escherichia coli. Baird Parker agar base and egg yolk tellurite emulsion (BPA, Merck) were used for Staphylococcus spp. counts. Lyophilised rabbit plasma (Newprov) was used in the coagulation test, followed by incubation at $7^{\circ} \mathrm{C}$ for ten days for $\mathrm{TVC}$, followed by incubation at $37^{\circ} \mathrm{C}$ for $48 \mathrm{~h}$ for coliforms and Staphylococcus spp. (FDA, 2015).

Salmonella spp. was established according to (FDA, 2015). The respective incubation in Rappaport Vassiliadis Soya Broth (RVS broth, Merck) and selenite cysteine (SC broth, Merck) was carried out at $42^{\circ} \mathrm{C}$ and $35^{\circ} \mathrm{C}$ for $24 \mathrm{~h}$. After this period, plates in lysine decarboxylase broth (Merck) and Hektoen enteric (HE agar, Merck) were incubated at $35^{\circ} \mathrm{C}$ for $24 \mathrm{~h}$. To preliminarily confirm colonies on triple sugar iron agar (TSI, Merck) and lysine iron agar (LIA, Merck), the incubation was conducted at $35^{\circ} \mathrm{C}$ for $24 \mathrm{~h}$. For the final confirmation through biochemical tests, mini kits were applied to Enterobacteria containing ten biochemical tests (Newprov).

For the enumeration of Clostridium sulphite reducers at $46^{\circ} \mathrm{C}$, at the time of use $1 \mathrm{~mL}$ of sterile $4 \%$ D-cycloserine was added to $100 \mathrm{~mL}$ of tryptose-sulphite-cycloserine agar (TSC, Merck). Aliquots of $1 \mathrm{~mL}$ were placed in sterile plates and $10 \mathrm{~mL}$ of TSC agar was added. After the agar solidified on a flat surface, a second layer of the same medium was added. The plates were incubated inverted in anaerobic jars (BBL GasPak) at $46^{\circ} \mathrm{C}$ for $48 \mathrm{~h}$. All microbial counts were converted to logarithms of colony-forming units per gram (log CFU/g) (FDA, 2015). 


\subsection{Statistical analysis}

Data were assessed through variance analysis (ANOVA). Least squares differences were used to compare the mean values for treatments and Tukey's HSD test was used to identify significant differences between treatments. Regression analysis was performed for the treatment and storage time interaction, both with a significance level of 5\%. SAS 9.1 was used to perform the analysis (SAS, 2004).

\section{Results and Discussion}

\subsection{Thickness and water vapor permeability (WVP) of active packing}

Table 2 show the results of thickness and water vapor permeability (WVP). Regardless of the type of oil and its amount, the addition of essential oils did not affect the thickness and permeability to water vapor $(\mathrm{P}>0.05)$. The presence of oil, due to its hydrophobic nature, may decrease the permeability to water vapor of biodegradable films, but in large quantity the presence of oil can cause discontinuity in the polymer chain, consequently increasing the permeability to water vapor (Shahbazi, 2017).

Table 2. Thickness and water vapor permeability (WVP) of active packing (mean's).

\begin{tabular}{lcc}
\hline Packaging & Thickness $(\mathrm{mm})$ & WVP $\left(\times 10^{-6}\right),\left(\mathrm{g} \mathrm{day}^{-1} \mathrm{~Pa}^{-1} \mathrm{~m}^{-1}\right)$ \\
\hline OR2 & $0.142^{\mathrm{a}}$ & $0.082^{\mathrm{a}}$ \\
CL2 & $0.134^{\mathrm{a}}$ & $0.074^{\mathrm{a}}$ \\
RO2 & $0.155^{\mathrm{a}}$ & $0.075^{\mathrm{a}}$ \\
ORCL1 & $0.130^{\mathrm{a}}$ & $0.080^{\mathrm{a}}$ \\
ORRO1 & $0.145^{\mathrm{a}}$ & $0.079^{\mathrm{a}}$ \\
CLRO1 & $0.143^{\mathrm{a}}$ & $0.073^{\mathrm{a}}$ \\
ORCLRO1/3 & $0.156^{\mathrm{a}}$ & $0.076^{\mathrm{a}}$ \\
\hline
\end{tabular}

a,b Means in the columns with the different letters differ significantly from samples at $P<0.05$. OR2: $2 \%$ oregano oil. CL2: $2 \%$ clove oil. RO2: 2\% rosemary oil. ORCL1: $1 \%$ oregano oil and 1\% clove oil. ORRO1: 1\% oregano oil and 1\% rosemary oil. CLRO1: $1 \%$ clove oil and 1\% rosemary oil. ORCLRO1/3: 0.66\% oregano, clove and rosemary oils. Source: Authors.

\subsection{Total phenolic and antioxidant activity of the packaging}

In all seven packaging the composition of total phenolic compounds were detected and expressed as content of soluble phenols (Table 3). The packaging containing clove oil (CL2) had the highest amount $(P<0.05)$ of total phenolic compounds, followed by the packaging containing ORCL1, CLRO1 and ORCLRO1/3. The packaging containing rosemary oil (RO2) had the lowest means, i.e., the least amount of phenolic compounds $(P<0.05)$.

Table 3. Phenolic total and antioxidant activity of active packing (mean's \pm standard error of the means).

\begin{tabular}{lccc}
\hline Packaging & TP $\left(\mu \mathrm{mol} \mathrm{GA} \cdot \mathrm{g}^{-1}\right)$ & DPPH $\left(\mu \mathrm{mol} \mathrm{TE} \mathrm{g}{ }^{-1}\right)$ & ORAC $\left(\mu \mathrm{mol} \mathrm{TE} \mathrm{g}^{-1}\right)$ \\
\hline OR2 & $1.76^{\mathrm{cd}} \pm 0.55$ & $4.06^{\mathrm{e}} \pm 1.40$ & $98.50^{\mathrm{c}} \pm 0.47$ \\
CL2 & $3.92^{\mathrm{a}} \pm 0.35$ & $19.92^{\mathrm{a}} \pm 1.68$ & $254.11^{\mathrm{a}} \pm 0.54$ \\
RO2 & $0.70^{\mathrm{e}} \pm 0.41$ & $8.33^{\mathrm{d}} \pm 1.14$ & $76.41^{\mathrm{d}} \pm 0.19$ \\
ORCL1 & $3.03^{\mathrm{b}} \pm 0.19$ & $17.69^{\mathrm{b}} \pm 1.24$ & $171.57^{\mathrm{b}} \pm 0.51$ \\
ORRO1 & $1.58^{\mathrm{d}} \pm 0.43$ & $7.15^{\mathrm{d}} \pm 1.66$ & $106.90^{\mathrm{c}} \pm 0.52$ \\
CLRO1 & $2.21^{\mathrm{c}} \pm 0.47$ & $16.29^{\mathrm{b}} \pm 1.33$ & $143.95^{\mathrm{b}} \pm 0.66$ \\
ORCLRO1/3 & $2.06^{\mathrm{c}} \pm 0.52$ & $12.87^{\mathrm{c}} \pm 1.46$ & $102.87^{\mathrm{c}} \pm 0.60$ \\
\hline
\end{tabular}

\footnotetext{
${ }^{a, b}$ Means in the columns with the different letters differ significantly from samples at $P<0.05$. GAE: Gallic acid equivalent. TE: Trolox equivalent. TP: total phenolic. DPPH: Scavenging of radical 2,2-diphenyl-1-picryhydrazyl. ORAC: oxygen radical absorbance capacity. OR2: 2\% oregano oil. CL2: $2 \%$ clove oil. RO2: $2 \%$ rosemary oil. ORCL1: $1 \%$ oregano oil and 1\% clove oil. ORRO1: $1 \%$ oregano oil and 1\% rosemary oil. CLRO1: $1 \%$ clove oil and $1 \%$ rosemary oil.

ORCLRO1/3: $0.66 \%$ oregano, clove and rosemary oils.
}

Source: Authors. 
The packaging antioxidant capacities (Table 3) were evaluated by DPPH and ORAC. The results show that packaging containing CL2, ORCL1 and CLRO1 had the highest $(P<0.05)$ antioxidant activity $\left(\mu \mathrm{mol} \mathrm{TE} \mathrm{g}^{-1}\right)$ by both methodologies, while

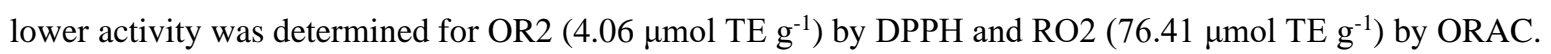

There was a positive correlation between antioxidant activity and total phenolic content, as samples with high antioxidant activity also had a high phenolic content. Comparing the essential oils used and the interaction between them, we observed the best results for clove (content of soluble phenols and antioxidant capacity). This can be explained by previous publications showing that clove has a high antioxidant activity (J Camo et al., 2008; Wojdyło et al., 2007).

\subsection{Lipid oxidation}

Lipid oxidation was evaluated through the levels of malondialdehyde per kilogram of sample developed during refrigerated storage for up to 15 days. Treatments OR2 (2\% oregano), RO2 (2\% rosemary) and ORRO1 (ORRO1; $1 \%$ oregano oil and $1 \%$ rosemary oil) resulted in higher $(P<0.05)$ lipid oxidation, while CL2 (2\% clove oil), ORCL1 (1\% oregano oil and $1 \%$ clove oil) and CLRO1 (1\% clove oil and 1\% rosemary oil) showed lower values of MDA $\mathrm{kg}^{-1}$. The results show that the incorporation of clove essential oil in active packaging retards lipid oxidation.

Figure 1 show the mean of the value corresponding to the increase in the malondialdehyde amount formed per mg sample during the storage period. MDA levels were below the acceptance limit, which is $0.2 \mathrm{mg} \mathrm{MDA} \mathrm{kg}^{-1}$ for fresh tissue (Campo et al., 2006). Thus, all active packaging acted like an antioxidant.

Figure 1. TBARS values on active packing of beef.

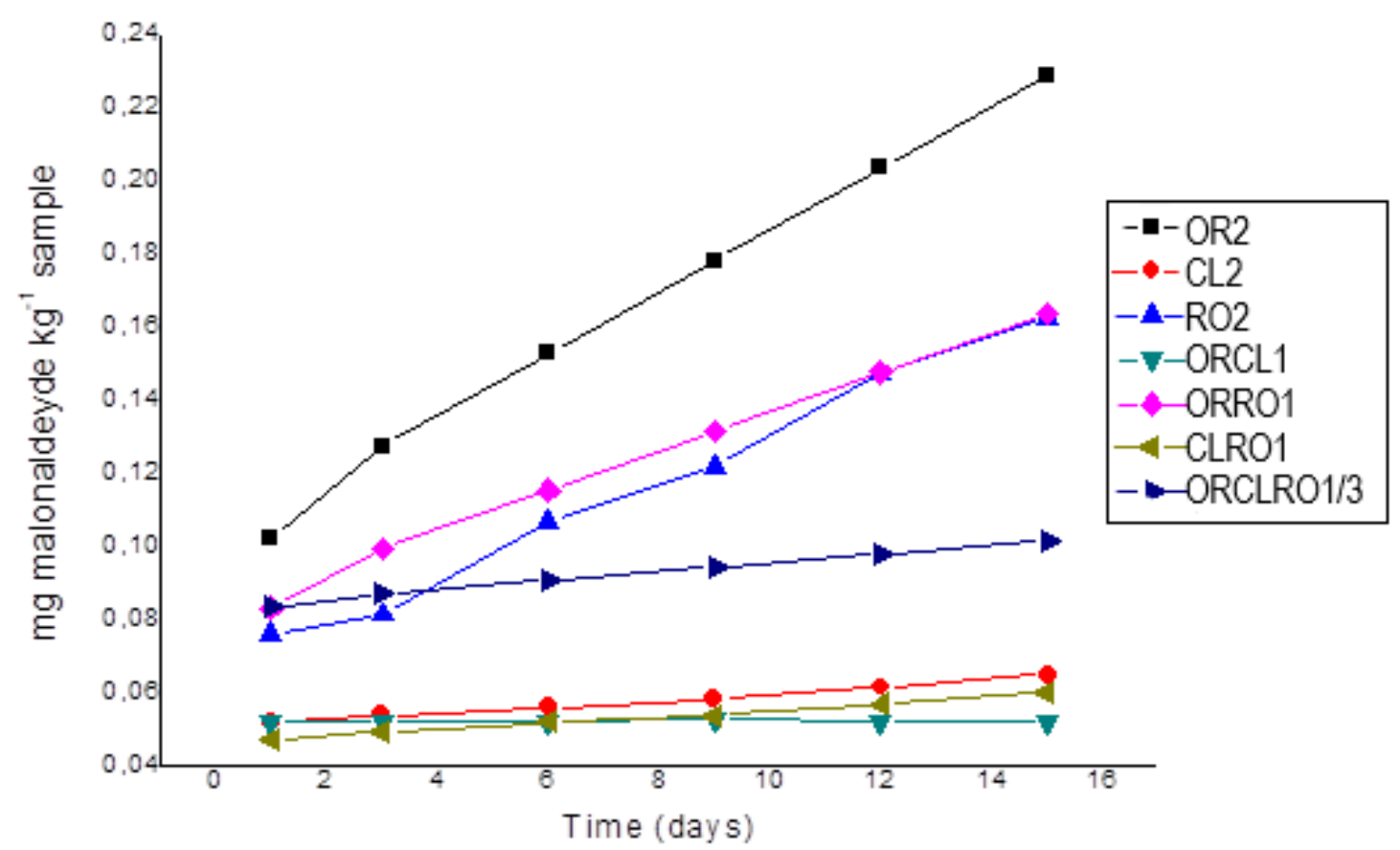

OR2: $2 \%$ oregano oil. CL2: $2 \%$ clove oil. RO2: $2 \%$ rosemary oil. ORCL1: $1 \%$ oregano oil and 1\% clove oil. ORRO1: $1 \%$ oregano oil and $1 \%$ rosemary oil. CLRO1: $1 \%$ clove oil and 1\% rosemary oil. ORCLRO1/3: 0.66\% oregano, clove and rosemary oils. Source: Authors.

Due to the variable compositions of EOs, some authors have postulated a potential synergistic effect between the components (Di Pasqua et al., 2005; Hernández-Ochoa et al., 2014). This effect may be due sequential inhibition of a common biochemical pathway, inhibition of protective enzymes, combinations of cell wall active agents, and the use of cell wall active agents to enhance uptake, as described by (Macwan et al., 2016). In this work, a synergistic effect between different oils was 
observed. The same packaging containing OR2, CL2 and RO2 were composed of $2 \%$ isolated oils, while the treatments ORCL1, ORRO1, CLRO1 and ORCLRO1/3 contained a mixture of EOs. The mixtures, especially in the packaging containing ORCL1 ( $1 \%$ oregano and $1 \%$ clove oil) and CLRO1 (1\% clove plus $1 \%$ rosemary oil) resulted in lower values of mg MDA kg-1; for both ORCL1 and CLRO1, the results are lower than 0.056 after 15 days of storage. This result is in agreement with the results obtained for the total phenolic and antioxidant activity of active packaging biodegradable in this study. It was noted that the films that presented high total phenolic and antioxidant activity inhibited lipid oxidation when applied to beef.

Others authors have succeeded in extending the shelf life of meat and meat products using active packaging with natural antioxidants (Barbosa-Pereira et al., 2014; J Camo et al., 2008; Contini et al., 2011). (Park et al., 2012) Park et al. (2012) developed vacuum active packaging containing antioxidant agents (thymol, carvacrol and eugenol) and applied it to beef patties, stored under refrigeration $\left(4^{\circ} \mathrm{C}\right)$. The packaging effectively inhibited lipid oxidation and positively affected colour stability.

\subsection{Microbiological analysis}

Salmonella spp. was absent in $25 \mathrm{~g}$ of all samples on days 0, 3 and 15. Coagulate positive Staphylococcus spp. was negative, Clostridium sulphite reducers were less than $10 \mathrm{CFU} / \mathrm{g}$ and Escherichia coli were not detected on all evaluation days. Total coliforms were found at $<1 \log \mathrm{CFU} / \mathrm{g}$ on days 0 and 3 and $<0.5 \log \mathrm{CFU} / \mathrm{g}$ on days 6, 912 and 15 for all treatments, with a reduction of more than $50 \%$ after 6 days.

This can be explained because EOs containing phenolic compounds that act mainly on the cell cytoplasmic membrane, i.e. compounds as carvacrol, thymol, $p$-cymene and $\gamma$-terpinene, are effective against Gram-positive and Gram-negative bacteria. This is, in part, due to the hydrophobicity of these EOs, making the structures of the cell membrane more permeable (Burt, 2004; Burt et al., 2005). Additionally, Burt et al. (2005) revealed that oregano and thyme EOs are active against $E$. coli. There is some evidence from studies with EOs in concentrations from $500 \mathrm{mg} / \mathrm{L}$ and $750 \mathrm{mg} / \mathrm{L}$ to be effective in meat against Escherichia coli, Salmonella, Clostridium perfringens and Staphylococcus aureus (Hernández-Ochoa et al., 2014).

In other studies, oregano and potassium sorbate in an active film reduced the total viable counts and total coliforms and delayed E. coli growth on low sodium restructured chicken steaks during 150 days of freezing storage (Cestari et al., 2015; Emiroğlu et al., 2010) incorporated (0, 1, 2, 3, 4 and 5\%) of oregano (OR) and thyme (TH) EOs in active packaging and evaluated their antimicrobial activity against Escherichia coli, Staphylococcus aureus, Pseudomonas aeruginosa and Lactobacillus plantarum during 12 days of refrigerated storage in ground beef and found that more than $3 \%$ of oregano and thyme EOs was effective in inhibiting these microorganisms.

\section{Conclusion}

All active packaging prolonged shelf life and sustained the oxidative and microbiological quality, and thus have possible uses as meat preservatives. The most effective packaging included clove oil (CL2, ORCL1 and CLRO1). These treatments demonstrated the highest total phenolic content and provided the greatest antioxidant activity compared to oregano and rosemary oils, and consequently was the most effective in retarding lipid oxidation in beef compared to other treatments.

\section{Acknowledgment}

The authors would like to thank the Brazilian Federal Agency for the support and Evaluation of Graduate Education (Coordenação de Aperfeiçoamento de Pessoal de Nível Superior, Brasil [CAPES]) and Conselho Nacional de Desenvolvimento Científico e Tecnológico - CNPq (400375/2014-1). 


\section{Conflict of interest}

The authors declare there are no conflicts of interest.

\section{References}

Anthony, K. P., Deolu-Sobogun, S. A., \& Saleh, M. A. (2012). Comprehensive assessment of antioxidant activity of essential oils. Journal of Food Science, 77(8), C839-C843. https://doi.org/10.1111/j.1750-3841.2012.02795.x.

Appendini, P., \& Hotchkiss, J. H. (2002). Review of antimicrobial food packaging. Innovative Food Science \& Emerging Technologies, 3(2), 113-126. https://doi.org/http://ac.els-cdn.com/S1466856402000127/1.

Barbosa-Pereira, L., Aurrekoetxea, G. P., Angulo, I., Paseiro-Losada, P., \& Cruz, J. M. (2014). Development of new active packaging films coated with natural phenolic compounds to improve the oxidative stability of beef. Meat Science, 97(2), 249-254. https://doi.org/10.1016/j.meatsci.2014.02.006.

Biondo, P. B. F., Carbonera, F., Zawadzki, F., Chiavellia, L. U. R., Pilau, E. J. P., Prado, I. N., \& Visentainer, J. V. (2017). Antioxidant capacity and identification of bioactive compounds by GC-MS of essential oils commercialized in Brazil. Current Bioactive Compounds, 13, 137-143. https://doi.org/10.2174/157340721266616061408084.

Bolumar, T., Andersen, M. L., \& Orlien, V. (2011). Antioxidant active packaging for chicken meat processed by high pressure treatment. Food Chemistry, 129(4), 1406-1412. https://doi.org/http://ac.els-cdn.com/S0308814611007850/1.

Brand-Williams, W., Cuvelier, M. E., \& Berset, C. L. W. T. (1995). Use of a free radical method to evaluate antioxidant activity. LWT-Food Science and Technology, 28(1), 25-30. https://doi.org/0023-6438/95/010025.

Burt, S. A. (2004). Essential oils: their antibacterial properties and potential applications in foods—a review. International Journal of Food Microbiology, 94(3), 223-253. https://doi.org/10.1016/j.ijfoodmicro.2004.03.022.

Burt, S. A., Vlielander, R., Haagsman, H. P., \& Veldhuizen, E. J. A. (2005). Increase in activity of essential oil components carvacrol and thymol against Escherichia coli O157: H7 by addition of food stabilizers. Journal of Food Protection, 68(5), 919-926.

Camo, J, Beltrán, J. A., \& Roncalés, P. (2008). Extension of the display life of lamb with an antioxidant active packaging. Meat Science, 80(4), 1086-1091. https://doi.org/10.1016/j.meatsci.2008.04.031.

Camo, Javier, Lorés, A., Djenane, D., Beltrán, J. A., \& Roncalés, P. (2011). Display life of beef packaged with an antioxidant active film as a function of the concentration of oregano extract. Meat Science, 88(1), 174-178. https://doi.org/10.1016/j.meatsci.2010.12.019.

Campo, M. M., Nute, G. R., Hughes, S. I., Enser, M., Wood, J. D., \& Richardson, R. I. (2006). Flavour perception of oxidation in beef. Meat Science, 72(2), 303-311. https://doi.org/10.1016/j.meatsci.2005.07.015.

Cestari, L. A., Gaiotto, R. C., Antigo, J. L., Scapim, M. R. S., Madrona, G. S., Yamashita, F., Pozza, M. S. S., \& Prado, I. N. (2015). Effect of active packaging on low-sodium restructured chicken steaks. Journal of Food Science and Technology, 52(6). https://doi.org/10.1007/s13197-014-1357-z.

Conde, R., Corrêa, V. S. C., Carmona, F., Contini, S. H. T., \& Pereira, A. M. S. (2011). Chemical composition and therapeutic effects of Lippia alba (Mill.) N. E. Brown leaves hydro-alcoholic extract in patients with migraine. Phytomedicine, 18(14), 1197-1201. https://doi.org/10.1016/j.phymed.2011.06.016.

Contini, C., Katsikogianni, M. G., 'O’Neill, F. T., 'O’Sullivan, M., Dowling, D. P., \& Monahan, F. J. (2011). Development of active packaging containing natural antioxidants. Procedia Food Science, 1, 224-228. https://doi.org/10.1016/j.profoo.2011.09.035.

Di Pasqua, R., De Feo, V., Villani, F., \& Mauriello, G. (2005). In vitro antimicrobial activity of essential oils from Mediterranean Apiaceae, Verbenaceae and Lamiaceae against foodborne pathogens and spoilage bacteria. Annals of Microbiology, 55(2), 139-143.

Eiras, C. E., Ornaghi, M. G., Valero, M. V., Rivaroli, D. C., Guerrero, A., \& Prado, I. N. (2016). How does the dietary cottonseed hull affect the carcass characteristics and meat quality of young bulls finished in a highconcentrate diet? Acta Scientiarum Animal Sciences, 38(3). https://doi.org/10.4025/actascianimsci.v38i3.32149.

Emiroğlu, Z. K., Yemiş, G. P., Coşkun, B. K., \& Candoğan, K. (2010). Antimicrobial activity of soy edible films incorporated with thyme and oregano essential oils on fresh ground beef patties. Meat Science, 86(2), 283-288. https://doi.org/10.1016/j.meatsci.2010.04.016.

FDA. (2015). Food and Drug Administration of the US, Substances used as GRAS in food. 21, CFR 184.

Gómez-Estaca, J., Lopez-de-Dicastillo, C., Hernandez-Munoz, P., Catala, R., \& Gavara, R. (2014). Advances in antioxidant active food packaging. Trends in Food Science \& Technology, 35(1), 42-51. https://doi.org/10.1016/j.tifs.2013.10.008.

Hernández-Ochoa, L., Aguirre-Prieto, Y. B., Nevárez-Moorillón, G. V, Gutierrez-Mendez, N., \& Salas-Muñoz, E. (2014). Use of essential oils and extracts from spices in meat protection. Journal of Food Science and Technology, 51(5), 957-963. https://doi.org/10.1007/s13197-011-0598-3.

Kempinski, E. M. B. C., Vital, A. C. P., Oliveira Monteschio, J., Alexandre, S., Nascimento, K. F., Madrona, G. S., Mikcha, J. M. G., \& Prado, I. N. (2017). Development and quality evaluation of infant food with oregano essential oil for children diagnosed with cerebral palsy. $L W T, 84,579-585$.

Ma, X., Wu, H., Liu, L., Yao, Q., Wang, S., Zhan, R., Xing, S., \& Zhou, Y. (2011). Polyphenolic compounds and antioxidant properties in mango fruits. Scientia Horticulturae, 129(1), 102-107. https://doi.org/10.1016/j.scienta.2011.03.015.

Macwan, S. R., Dabhi, B. K., Aparnathi, K. D., \& Prajapati, J. B. (2016). Essential oils of herbs and spices: Their antimicrobial activity and application in 
preservation of food. International Journal of Current Microbiology and Applied Sciences, 5(5), 885-901. https://doi.org/10.20546/ijcmas.2016.505.092.

Michiels, J. A., Kevers, C., Pincemail, J., Defraigne, J. O., \& Dommes, J. (2012). Extraction conditions can greatly influence antioxidant capacity assays in plant food matrices. Food Chemistry, 130(4), 986-993. https://doi.org/10.1016/j.foodchem.2011.07.117.

Monteschio, J. de O., Souza, K. A. de, Vital, A. C. P., Guerrero, A., Valero, M. V., Kempinski, E. M. B. C., Barcelos, V. C., Nascimento, K. F., \& Prado, I. N. (2017). Clove and rosemary essential oils and encapsuled active principles (eugenol, thymol and vanillin blend) on meat quality of feedlot-finished heifers. Meat Science, 130, 50-57. https://doi.org/10.1016/j.meatsci.2017.04.002

Ou, B., Hampsch-Woodill, M., \& Prior, R. L. (2001). Development and validation of an improved oxygen radical absorbance capacity assay using fluorescein as the fluorescent probe. Journal of Agricultural and Food Chemistry, 49(10), 4619-4626. https://doi.org/10.1021/jf010586o.

Pereira A.S. et al. (2018). Metodologia da pesquisa científica. UFSM. https://repositorio.ufsm.br/bitstream/handle/1/15824/Lic_Computacao_MetodologiaPesquisa-Cientifica.pdf?sequence $=1$

Park, H., Kim, S., Kim, K. M., You, Y., Kim, S. Y., \& Han, J. (2012). Development of antioxidant packaging material by applying corn-zein to LLDPE film in combination with phenolic compounds. Journal of Food Science, 77(10), E273-E279. https://doi.org/10.1111/j.1750-3841.2012.02906.x.

Pfalzgraf, A., Frigg, M., \& Steinhart, H. (1995). Alpha tocopherol contents and lipid oxidation in pork muscle and adipose tissue during storage. Journal of Agricultural and Food Chemistry, 43(5), 1339-1342. https://doi.org/0021-8561/95/1443.

Radha, K. K., Babuskin, S., Azhagu, S. B. P., Sasikala, M., Sabina, K., Archana, G., Sivarajan, M., \& Sukumar, M. (2014). Antimicrobial and antioxidant effects of spice extracts on the shelf life extension of raw chicken meat. International Journal of Food Microbiology, 171, 32-40. https://doi.org/10.1016/j.ijfoodmicro.2013.11.011.

Realini, C. E., \& Marcos, B. (2014). Active and intelligent packaging systems for a modern society. Meat Science, 98(3), 404-419. https://doi.org/10.1016/j.meatsci.2014.06.031.

Rivaroli, D. C., Guerrero, A., Velandia Valero, M., Zawadzki, F., Eiras, C. E., Campo, M. M., Sañudo, C., Jorge, A. M., \& Prado, I. N. (2016). Effect of essential oils on meat and fat qualities of crossbred young bulls finished in feedlots. Meat Science, 121. https://doi.org/10.1016/j.meatsci.2016.06.017

SAS. (2004). SAS/STAT User guide, Version 9.1.2. SAS Institute Inc.

Shah, M. A., Bosco, S. J. D., \& Mir, S. A. (2014). Plant extracts as natural antioxidants in meat and meat products. Meat Science, 98(1), 21-33. https://doi.org/10.1016/j.meatsci.2014.03.020.

Shahbazi, Y. (2017). The properties of chitosan and gelatin films incorporated with ethanolic red grape seed extract and Ziziphora clinopodioides essential oil as biodegradable materials for active food packaging. International Journal of Biological Macromolecules, 99, 746-753. https://doi.org/10.1016/j.ijbiomac.2017.03.065.

Singleton, V. L., \& Rossi, J. A. (1965). Colorimetry of total phenolics with phosphomolybdic-phosphotungstic acid reagents. American Journal of Enology and Viticulture, 16(3), 144-158.

Vital, A. C. P., Guerrero, A., Monteschio, J. O., Valero, M. V., Carvalho, C. B., Abreu Filho, B. A., Madrona, G. S., \& Prado, I. N. (2016). Effect of Edible and Active Coating (with Rosemary and Oregano Essential Oils) on Beef Characteristics and Consumer Acceptability. PLOS ONE, 11 (8), e0160535. https://doi.org/10.1371/journal.pone.0160535

Wojdyło, A., Oszmiański, J., \& Czemerys, R. (2007). Antioxidant activity and phenolic compounds in 32 selected herbs. Food Chemistry, 105(3), 940-949. https://doi.org/10.1016/j.foodchem.2007.04.038.

Wu, J.-H., Tung, Y.-T., Wang, S.-Y., Shyur, L.-F., Kuo, Y.-H., \& Chang, S.-T. (2005). Phenolic antioxidants from the heartwood of Acacia confusa. Journal of Agricultural and Food Chemistry, 53(15), 5917-5921. https://doi.org/10.1021/jf050550m.

Zulueta, A., Esteve, M. J., \& Frígola, A. (2009). ORAC and TEAC assays comparison to measure the antioxidant capacity of food products. Food Chemistry, 114(1), 310-316. https://doi.org/10.1016/j.foodchem.2008.09.033. 